УДК 338.439

DOI: https://doi.org/10.37320/2415-3583/12.8

Корман I.I.

кандидат економічних наук, доцент, Уманський національний університет садівництва ORCID: https://orcid.org/0000-0002-0332-6132

\title{
СУЧАСНИЙ СТАН ТА ПЕРСПЕКТИВИ РОЗВИТКУ ВІТЧИЗНЯНОГО РИНКУ РИБИ ТА РИБОПРОДУКТІВ
}

В усьому світі збільшують обсяги вилову та споживання риби. Середньорічний показник споживання риби та рибопродуктів в Украӥні значно нижчий за середньосвітовий. У 2018 році Украӥна посідала 10 позицію серед краӥн Європи за обсягами вилову риби та рибопродуктів. Ринок риби в Україні представлений перш за все імпортною продукцією. Найближчими роками не слід очікувати суттєвого покращення ситуації з наповненням внутрішнього ринку рибною продукцією украӥнського видобутку. Рибне господарство Украӥни перебуває в занедбаному стані. Основними факторами, щуо впливають на обсяги споживання риби та рибопродуктів, є їх ціна та рівень доходів населення. Україна в змозі забезпечити більше половини власних потреб у морепродуктах. Для иьього потрібно розвивати й підтримувати вітчизняне рибне господарство, а також забезпечувати належний рівень життя населення.

Ключові слова: ринок риби, вилов риби та рибопродуктів, споживання риби та рибопродуктів, експорт риби, імпорт риби.

Постановка проблеми. Виробництво та споживання риби і рибних продуктів є одними з важливих показників економічного та соціального рівнів розвитку країни. У світовому масштабі попит на рибу та морепродукти з року в рік зростає, особливо в промислово розвинених країнах. Державам, що розвиваються, така тенденція приносить збільшення надходжень від реалізації та сприяє створенню нових робочих місць. Нині в секторі рибного господарства постійно працюють майже 45 млн. осіб [1]. Нині на частку риби припадають 18\% тваринного білка в харчовому раціоні населення планети й 7\% усього споживаного ним білка. Споживання риби росте швидше, ніж споживання м'яса всіх сухопутних тварин загалом [2].

В Україні на сучасному етапі рівень виробництва, отже, рівень споживання риби та рибопродуктів значно нижче загальносвітових показників, тому аналіз основних тенденцій стану та розвитку ринку риби $є$ актуальним.

Аналіз останніх досліджень і публікацій. Проблема економічного розвитку рибного господарства та ринку риби і рибопродуктів України розглядалася в працях вітчизняних науковців. Перспективам розвитку вітчизняного ринку риби і рибопродукції присвячені роботи П.Т. Саблука, П.П. Борщевського, М.С. Стасишена, С.I. Алимова, О.В. Загороднюк [3], А.В. Захарчук [4], О.С. Курганської [5] та інших учених. Проте, незважаючи на те, що проблеми розвитку рибного господарства є предметом багатьох наукових досліджень, багато питань залишаються невирішеними.

Зокрема, існують проблеми адаптації ринку риби та рибопереробної галузі до сучасних умов господарювання через різке зростання цін на імпортну рибу для споживачів та як промислову сировину, зменшення територій вилову риби та рибопродуктів.

Мета статті полягає в аналітичному оцінюванні сучасного стану та напрямів розвитку ринку риби та рибопродуктів України.

Виклад основного матеріалу. Сьогодні риба та рибна продукція посідає важливе місце у світовій торгівлі. У 2016 році частка виробленої у світі риби (харчової і нехарчової), яка в різних формах потрапила на міжнародні товарні ринки, склала 35\%. Загальний обсяг світового експорту риби і рибопродуктів у 2016 році склав 60 млн. т, що на 245\% більше, ніж у 1976 році. За той же період значно збільшився обсяг світової торгівлі рибою та морепродуктами в грошовому вираженні, адже експорт зріс із 8 млрд. дол. США у 1976 році до 143 млрд. дол. США у 2016 році [2].

В усьому світі збільшуються обсяги вилову та споживання риби. Так, останніми роками світовий середньорічний обсяг споживання риби на одну людину щорічно зростає. У 1960-і роки цей показник у середньому становив 9,9 кг, у 1990-і роки - 14,4 кг, а вперше перевищив 20 кг у 2016 році (табл. 1). При цьому у високорозвинених країнах цей показник може бути більше у 2-3 рази.

За результатами 2019 року середнє споживання риби у світі на одну людину в рік склало 20,5 кг. При цьому найбільше споживання риби на людину в рік традиційно спостерігається в Океанії (27,5 кг), далі йдуть Азія (25,1 кг), Північна Америка (23,7 кг), Свропа (21,6 кг), Південна Америка (10,7 кг) і Африка $(9,8$ кг).

Слід зазначити, що вже кілька десятків років обсяги промислу у світі істотно не змінюються, складаючи близько 90 млн. т на рік. Збільшення обсягів відбувається лише за рахунок розвитку аквакультури (контрольованого вирощування риби).

Світовий промисел за 2016 рік становив 90,9 млн. т. Основними промисловими видами є минтай (3,5 млн. т), перуанський анчоус (3,2 млн. т), смугастий тунець (2,8 млн. т), сардинели, ставриди, оселедець атлантичний, скумбрія японська, тунець жовтоперий, тріска атлантична, японський анчоус тощо.

Обсяг аквакультури за 2016 рік склав 80 млн. т. У 2016 році було вирощено 54,1 млн. т риби, 17,1 млн. т молюсків, 7,9 млн. т ракоподібних і 938500 т інших водних тварин. Першість у світовій аквакультурі беззастережно належить Китаю, адже він не тільки випередив інші країни у 2016 році, але й з 1991 року вирощує 
Таблиця 1 - Світовий рибний ринок в цифрах, млн. т

\begin{tabular}{|c|c|c|c|c|c|}
\hline \multirow{2}{*}{ Показник } & \multicolumn{4}{|c|}{ Роки } & \multirow{2}{*}{$\begin{array}{c}\text { Відхилення } 2019 \text { року } \\
\text { від } 2018 \text { року, \% }\end{array}$} \\
\hline & 2016 & 2017 & 2018 & 2019 & \\
\hline Виробництво & 170,9 & 172,6 & 177,7 & 177,8 & 0 \\
\hline Рибальство & 90,9 & 92,5 & 94,5 & 91,3 & $-3,4$ \\
\hline Аквакультура & 80,0 & 80,1 & 83,2 & 86,5 & 3,9 \\
\hline Обсяг торгівлі (жива вага) & 59,5 & 64,9 & 65,1 & 64,3 & $-1,2$ \\
\hline Загальне споживання & 170,9 & 172,6 & 177,7 & 177,8 & 0 \\
\hline зокрема, харчування & 151,2 & 153,4 & 155,7 & 158,2 & 1,6 \\
\hline корм & 14,6 & 14,6 & 17,5 & 15,0 & $-14,2$ \\
\hline інше використання & 5,1 & 4,7 & 4,6 & 4,6 & 0 \\
\hline $\begin{array}{l}\text { На душу населення споживання продуктів } \\
\text { харчування, а саме риби харчової (кг/рік) }\end{array}$ & 20,3 & 20,3 & 20,4 & 20,5 & 0,6 \\
\hline зокрема, від рибальства (кг/рік) & 9,5 & 9,7 & 9,5 & 9,3 & $-2,0$ \\
\hline 3 аквакультури (кг/рік) & 10,7 & 10,6 & 10,9 & 11,2 & 2,8 \\
\hline
\end{tabular}

Джерело: [6]

більше риби, ніж усі інші країни світу разом. У число найбільших виробників у 2016 році увійшли Бангладеш, В’єтнам, Єгипет, Індія, Індонезія і Норвегія [2].

Ринок риби та рибопродуктів України поки що далекий не тільки від насичення, але й навіть від мінімального задоволення внутрішніх потреб населення країни. Середньорічний показник споживання риби та рибопродуктів в Україні, за даними Державної служби статистики України, значно нижче за середньосвітовий (рис. 1).

Ресурси внутрішніх водойм і виключно морської економічної зони України зараз можуть забезпечити пропозицію щонайбільше в обсязі 92 тис. т. риби та рибопродуктів. Протягом тривалого часу основну частину добутих водних живих ресурсів становила риба: від 98\% у 2010 році до $88 \%$ у наступні роки. Лише у 2018 році частка риби у загальному обсязі вилову зменшилася до 75\%, а у 2019 році вона становила $63 \%$.

Рибне господарство України перебуває в занедбаному стані, адже зношеність національного риболовецького флоту, застаріла матеріально-технічна база, недосконалі технології, нераціональне використання наявних виробничих потужностей, відсутність інвестицій у галузь не можуть належним чином забезпечити iï функціонування.

Крім того, суттєве падіння промислового видобутку риби з 2014 року на території України обумовлене анексією Криму, який забезпечував надходження на внутрішній ринок майже двох третин біоресурсів. У 2019 році відбулося незначне зростання обсягу вилову риби та рибопродуктів, переважно за рахунок збільшення вилову в інших регіонах промислу, тоді як обсяг вилову риби у внутрішніх водоймах скоротився майже вдвічі порівняно з попереднім роком.

У 2018 році вилов риби та рибопродуктів в Україні був низьким порівняно з країнами Свропи. За даними Євростату серед європейських країн найбільший видобуток риби та рибопродуктів у 2018 році був у Норвегії, Данії, Великобританії, Нідерландах, Туреччині, Німеччині, Швеції, Польщі та Фінляндії [8].

Як видно з рис. 2, у 2018 році Україна займала 10 позицію серед країн Європи за обсягами вилову риби та рибопродуктів.

Найближчими роками не слід очікувати суттєвого покращення ситуації iз наповненням внутрішнього ринку рибною продукцією українського видобутку, оскільки цей процес $\epsilon$ довготривалим та потребує значних інвестиційних ресурсів.

У 2019 році українськими компаніями-імпортерами було ввезено 394000 тон риби і рибопродуктів загальною вартістю 750 млн. доларів США.

Морепродукти 3 розряду делікатесів поступово перейшли в розряд продукції, яка часто споживається. Оціночна ємність українського ринку рибопродуктів ще у 2006 році складала 1 млрд. дол. США, 3 того часу спостерігався щорічний приріст обсягів цього сегменту ринку. Пов'язують такий швидкий ріст зі збільшенням доходів українців. Ще однією причиною зростання популярності рибопро- 
дуктів фахівці вважають перехід до здорового способу життя, що відбивається на виборі продуктів харчування, насичених корисними речовинами, однак дієтичних.

Показник споживання риби та рибопродуктів в Україні на душу населення у 2019 році зріс на 9,3\%, а саме до 12,9 кг. Це пов'язано зі збільшенням вилову (добування) водних біоресурсів та постачанням імпортованої рибної продукції в Україну у 2019 році. Споживання риби та рибопродуктів зросло до 555 тис. т. У 2018 році цей показник складав 497 тис. т. Середні споживчі ціни на рибу та рибопродукти у 2019 році збільшилися на 6,4\%.

За даними Держрибагентства у 2019 році імпорт риби, рибної продукції та інших водних біоресурсів в Україну складав 399,1 тис. т, що на 5,2\% більше, ніж у 2018 році, адже за сумою імпорт зріс на 18,5\%, а саме до $\$ 753,2$ млн.

Водночас вартість експорту риби, рибної продукції та інших водних біоресурсів у 2019 році збільшилась на 24,9\%, адже протягом 2019 року було експортовано 11,8 тис. т риби та продукції з водних біоресурсів на загальну суму $\$ 46,4$ млн.

Головними імпортерами водних біоресурсів в Україну є Ісландія, Норвегія та Естонія (45,2\%). Крім зазначених країн, поставки у великих обсягах імпортної рибопродукції здійснюються із США, Латвії, Канади, Іспанії, Китаю та Великобританії.

Експорт з України переважно здійснюється до країн Свропи (Данія, Німеччина, Франція, Литва тощо близько 37\%), до країн Азії (Туреччина, Корея, Грузія тощо - 29\%) та до країн СНД (Молдова, Азербайджан, Білорусь тощо - 30\%).

У внутрішніх водоймах у минулому році виловлено 21,3 тис. т (ріст на 4,3\% до показника 2018 року), тоді як в Азовському морі - 16,1 тис. т (зменшення на 24,8\%), а в Чорному морі - 14,1 тис. т (ріст на 64\%). В Азово-Чорноморському басейні на промисел бичка, тюльки, шпротів, хамси та рапанів припадає понад 90\% усього вилову.

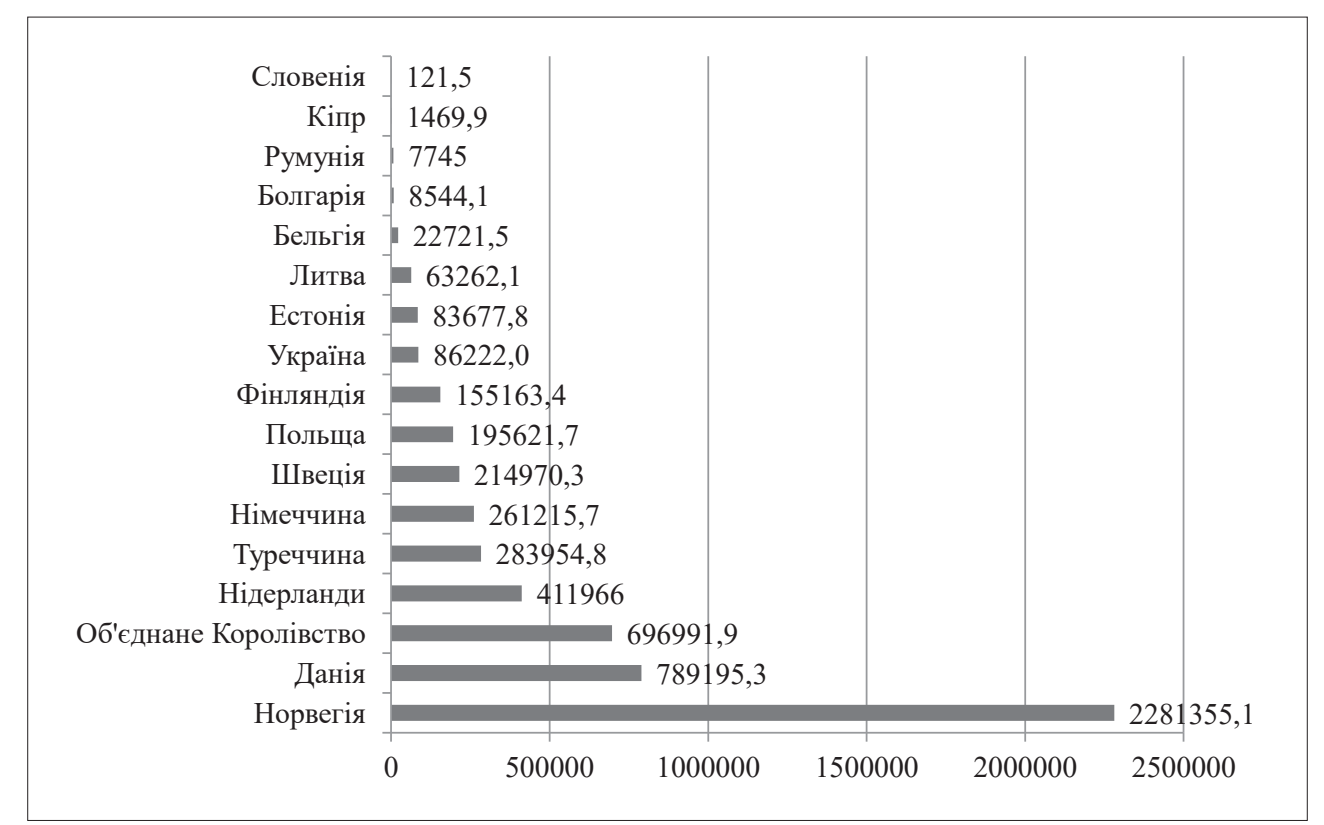

Рисунок 2 - Вилов риби та рибопродуктів у деяких країнах Європи у 2018 році

Джерело: побудовано на основі джерел [7;8]

Таблиця 2 - Обсяги вилову риби та рибопродуктів в Україні за 2010-2019 роки, т

\begin{tabular}{|c|c|c|c|c|}
\hline \multirow{2}{*}{ Рік } & \multicolumn{3}{|c|}{ Вилов риби та рибопродуктів } & \multirow{2}{*}{ Зокрема, вилов риби } \\
\cline { 2 - 4 } & \multirow{2}{*}{ всього } & \multicolumn{2}{|c|}{ у тому числі } & \\
\cline { 3 - 4 } & & у внутрішніх водоймах & інші регіони промислу & 215017 \\
\hline 2010 & 218681 & 38364 & 180317 & 205285 \\
\hline 2011 & 211182 & 37574 & 173608 & 195490 \\
\hline 2012 & 203926 & 41569 & 162357 & 216354 \\
\hline 2013 & 225802 & 45695 & 180107 & 80958 \\
\hline 2014 & 91252 & 39612 & 51640 & 73963 \\
\hline 2015 & 88552 & 38507 & 50045 & 81875 \\
\hline 2016 & 88443 & 40754 & 47689 & 64738 \\
\hline 2017 & 92645 & 42176 & 50469 & 58096 \\
\hline 2018 & 86222 & 46820 & 39402 & \\
\hline 2019 & 92682 & 22929 & 69753 & \\
\hline
\end{tabular}

Джерело: [7] 
Судна під державним прапором України у 2019 році в Антарктиці добули 22,4 тис. т водних біоресурсів, що перевищило показник 2018 року на 48,7\% (15,1 тис. т) [9].

Основними факторами, що впливають обсяги споживання риби та рибопродуктів, $є$ їх ціна та рівень доходів населення. На основі даних про обсяги споживання риби і рибопродуктів можна визначити залежність попиту від ціни для цього товару (рис. 3, 4).
Оскільки риба може бути альтернативним джерелом білка для організму людей і ціна риби зазвичай нижче за ціну м'яса, зміна цін на рибу більш еластична і дає можливість виробникам зберігати попит на свою продукцію. За зростання ціни зсув може бути в бік більш дешевих сортів риби.

Як бачимо 3 рис. 3, ціни на рибу та рибопродукти найбільше зростали у 2014 та 2015 роках. Це було

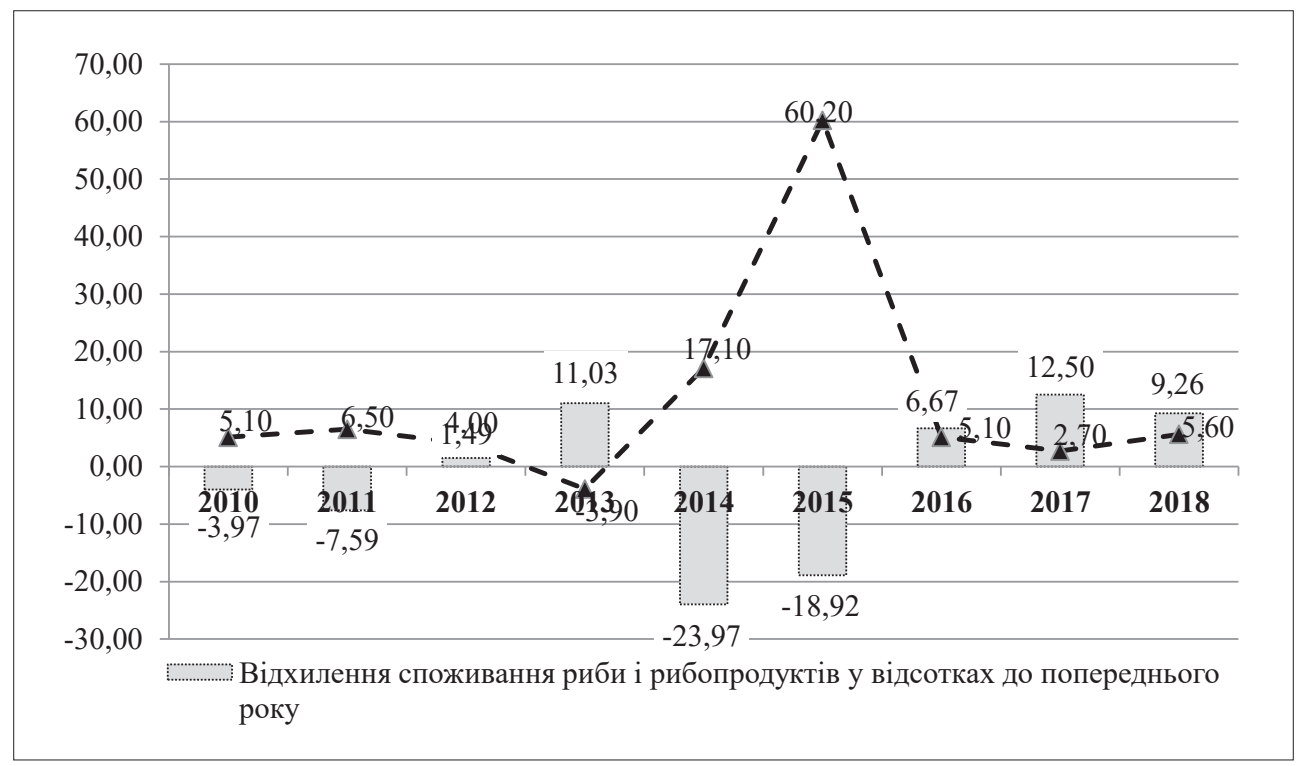

Рисунок 3 - Зміна обсягів споживання риби залежно від зміни ціни на неї, 2010-2018 роки

Джерело: розраховано, побудовано автором на основі даних джерела [7]

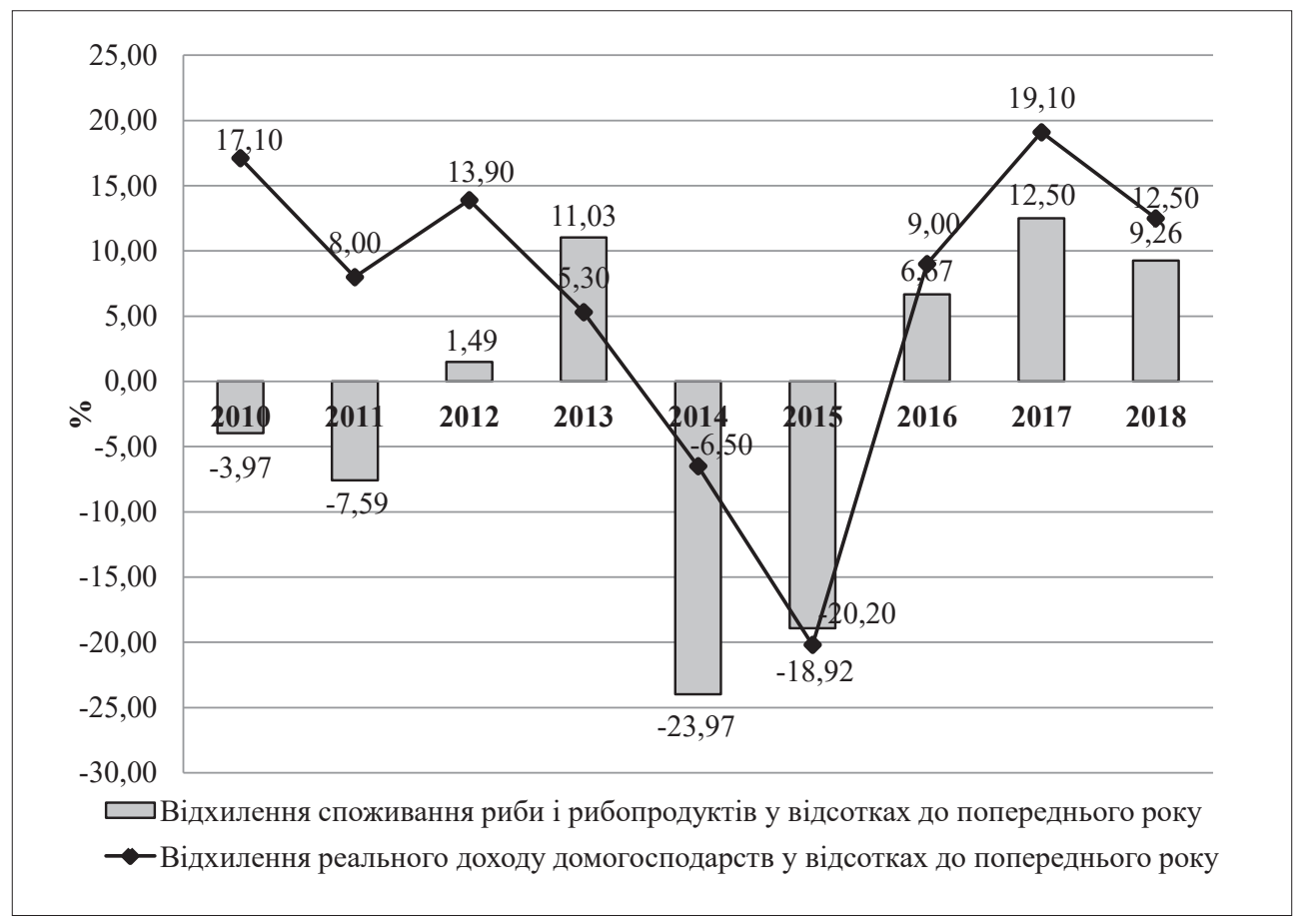

Рисунок 4 - Зміна обсягів споживання риби 3 алежно від зміни реального доходу домогосподарств, 2010-2018 роки

Джерело: розраховано, побудовано автором на основі даних джерела [7] 
пов'язано з різким знеціненням національної валюти, що відразу ж відобразилося на ціні імпортованої риби та рибної сировини, частка якої перевищувала обсяги власної виловленої риби. В цей же період (2014-2015 роки) відбулося різке зменшення рівня реальних доходів населення. Відповідно, обсяг споживання риби також значно скоротився.

Виробництво риби та рибопродуктів належить до базових галузей Україні. За оцінками експертів Україна в змозі забезпечити більше половини власних потреб у морепродуктах. Для цього потрібно розвивати й підтримувати вітчизняне рибне господарство, а також забезпечити належний рівень життя населення.

Висновки. Ринок риби в Україні представлений перш за все імпортною продукцією, а прогнози аналітиків свідчать про те, що країна буде залишатися імпортозалежною державою ще значний час.

Слід зазначити, що покращення ситуації є можливим за рахунок збільшення видобутку та виробництва власної рибної продукції, підвищення якості об'єктів аквакультури, відновлення природних нерестовищ у рибогосподарських водоймах, стимулювання просування вітчизняної рибної продукції на внутрішній i зовнішній ринки за рахунок розширення асортименту та зростання якості.

Реалізація зазначених завдань допоможе покращити становище вітчизняних підприємств рибного господарства та рибопереробної промисловості, сприятиме економічному розвитку країни, посиленню продовольчої безпеки та підвищенню рівня конкурентоспроможності національної економіки.

Сьогодні, коли Україна перебуває в глибокій кризі, держава не в змозі здійснювати фінансування галузі за рахунок коштів державного бюджету, тому постає питання залучення інвестицій, зокрема іноземних.

Також важливо здійснити співробітництво $з$ країнами-партнерами у сфері спільного вивчення сировинних ресурсів, рибопереробки й маркетингу створення інфраструктури рибогосподарської галузі, підготовки фахівців тощо. Ці заходи будуть сприяти підвищенню конкурентоспроможності вітчизняної рибної продукції на внутрішніх та зовнішніх ринках, посиленню продовольчої безпеки України.

\section{Список використаних джерел:}

1. Офіційний сайт Державного агентства рибного господарства України. URL: http://darg.gov.ua (дата звернення: 16.06.2020).

2. Огляд рибного ринку України за 2019 рік. UIFSA. URL: http://uifsa.ua/uk/news/news-of-ukraine/overview-of-the-fishmarket-of-ukraine-in-2019 (дата звернення: 14.06.2020).

3. Загороднюк О.В. Формування та розвиток ринку риби і рибної продукції України : автореф. дис. ... канд. екон. наук : спец. 08.00.03 «Економіка і управління національним господарством». Одеса, 2012. 24 с.

4. Захарчук Я.В., Бебешко К.С. Економічний аналіз діяльності рибного господарства України. Вісник Дніпропетровського університету. 2012. № 2. С. 68-74.

5. Курганська О.С., Клименко О.В. Сучасний стан, перспективи, проблеми та напрями реформування рибного господарства в Україні. Актуальні проблеми економіки та управління. 2012. № 3. С. 48-54.

6. GLOBEFISH - Information and Analysis on World Fish Trade. Food and Agriculture Organization of the United Nations. URL: http://www.fao.org/in-action/globefish/fishery-information/world-fish-market/en (дата звернення: 15.06.2020).

7. Державна служба статистики України. URL: http://www.ukrstat.gov.ua (дата звернення: 15.06.2020).

8. Catches in all fishing regions. Eurostat. URL: https://ec.europa.eu/eurostat/databrowser/view/tag00076/default/table?lang=en (дата звернення: 15.06.2020).

9. Споживання риби українцями у 2019 році зросло на 9,3\% - Держрибагентство. Mind. URL: https://mind.ua/news/20207874spozhivannya-ribi-ukrayincyami-u-2019-roci-zroslo-na-93-derzhribagentstvo (дата звернення: 15.06.2020).

\section{References:}

1. Official site of the State Agency of Fisheries of Ukraine (2020). Available at: http://darg.gov.ua (accessed: 16 June 2020).

2. Oglyad ry'bnogo ry'nku Ukrayiny' za 2019 rik (2020) [Review of the fish market of Ukraine for 2019] UIFSA. http://uifsa.ua/ uk/news/news-of-ukraine/overview-of-the-fish-market-of-ukraine-in-2019 (accessed: 14 June 2020).

3. Zagorodnyuk O.V. (2012) Formuvannya ta rozvy'tok ry'nku ry'by' i ry'bnoyi produkciyi Ukrayiny'. [Formation and development of the fish and fish products market of Ukraine] (PhD Thesis), Odesa.

4. Zaxarchuk Ya.V., Bebeshko K.S. (2012) Ekonomichny'j analiz diyal'nosti ry'bnogo gospodarstva Ukrayiny' [Economic analysis of fisheries in Ukraine]. Bulletin of Dnipropetrovsk University, no. 2, pp. 68-74.

5. Kurgans'ka O.S., Kly'menko O.V. (2012) Suchasny'j stan, perspekty'vy', problemy' ta napryamy' reformuvannya ry'bnogo gospodarstva v Ukrayini. [Current state, prospects, problems and directions of fisheries reform in Ukraine]. Current problems of economics and management, no. 3, pp. 48-54.

6. GLOBEFISH - Information and Analysis on World Fish Trade (2019) Food and Agriculture Organization of the United Nations. Available at: http://www.fao.org/in-action/globefish/fishery-information/world-fish-market/en (accessed: 15 June 2020).

7. State Statistics Service of Ukraine (2020). Available at: http://www.ukrstat.gov.ua (accessed: 15 June 2020).

8. Catches in all fishing regions (2020). Eurostat. Available at: https://ec.europa.eu/eurostat/databrowser/view/tag00076/default/ table?lang=en (accessed: 15 June 2020).

9. Derzhry’bagentstvo (2020) Spozhy’vannya ry’by' ukrayincyamy' u 2019 roci zroslo na 9,3\%. [Consumption of fish by Ukrainians in 2019 increased by 9.3\% - State Fisheries Agency]. Mind. Available at: https://mind.ua/news/20207874-spozhivannyaribi-ukrayincyami-u-2019-roci-zroslo-na-93-derzhribagentstvo (accessed: 15 June 2020). 
Korman Iryna

Uman National University of Horticulture

\section{CURRENT STATE AND PROSPECTS OF DEVELOPMENT OF THE DOMESTIC FISH AND FISH PRODUCTS MARKET}

The purpose of the article is to analytically assess the current state and directions of development of the fish and fish products market in Ukraine. Production and consumption of fish and fish products is one of the important indicators of economic and social development. In Ukraine at this stage the level of production and hence consumption of fish and fish products is much lower global indices as analysis of major trends in the state and development of the fish is important. The theoretical and methodological basis of the research is a systematic approach to the study of economic and organizational aspects of fisheries development and scientific works of domestic and foreign scientists on the functioning of the market of fish and fish products. The information base of the study was the materials of the State Statistics Committee of Ukraine and Eurostat, the author's personal research. In the process of research general scientific and economic methods were used: monographic method (in statement of a problem and definition of conclusions); calculation and design method (when determining the change in fish consumption depending on changes in its price and the real level of income). The study found that the level of fish consumption per capita in Ukraine is much lower than in developed countries. In terms of fish catch, Ukraine ranks 10th among European countries. Fishing has decreased significantly due to the significant wear and tear of the national fishing fleet, the irrational use of existing production facilities, and the annexation of Crimea. A significant share of supply in the market of fish and fish products is imports. The main factors influencing the volume of demand for fish and fish products - price and income level. As the fish market is import-dependent, the devaluation of the national currency leads to higher prices for fish and fish products. Improving the situation is possible by increasing the production and production of own fish products, improving the quality of aquaculture facilities; restoration of natural spawning grounds in fishery reservoirs; stimulating the promotion of domestic fish products on the domestic and foreign markets by expanding the range and improving quality.

Key words: fish market, fish and seafood catch, fish and seafood consumption, fish export, fish import.

JEL classification: M31, Q13, Q22 